\title{
FINANCING AND PAYBACK OF RENEWABLE HYBRID ENERGY PROJECT (TECHNOLOGY) SUCH AS PV-MFC SYSTEMS: CASE STUDY UMHLATHUZE MHLATHUZE MUNICIPALITY
}

\author{
MELUSI NHLEKO \& FREDDIE L. INAMBAO*
}

Department of Mechanical Engineering, University of KwaZulu-Natal, Durban, South Africa

\begin{abstract}
Renewable energy based hybridised systems are considered to be the future of electricity generation and the most costeffective means of attempting to satisfy energy generation targets and development goals in the immediate and near future. Although, the feasibility of hybridised systems seems certain in the energy sector, the sourcing of funds to finance the implementation of systems such as photovoltaic microbial fuel cells (PV-MFC) technology is difficult. This paper attempts to indicate the financing models that can be pursued with great confidence by organisations such as uMhlathuze municipality. When considering funding issues, it is appropriate to consider the targeted payback period of the 'initial' (feasibility and capital) investment made. Three funding mechanisms have been identified as potential avenues that the municipality can pursue together with identified advantages and disadvantages. The cost-benefit analysis is briefly described in evaluating the feasibility or readiness of a project for implementation. Lastly, the payback period is briefly outlined from the perspective of using different tools such as net present value (NPV), return on investment (ROI) to establish the costs of pursuing such a project against planned payback targets.

KEYWORDS: Funding, Efficiency, Payback, Renewable Energy Project, PV-MFC Hybrid Technology, Photovoltaic, Microbial Fuel Cells.
\end{abstract}

Received: Feb 14, 2021; Accepted: Mar 04, 2021; Published: Mar 27, 2021; Paper Id.: IJMPERDJUN20211

\section{INTRODUCTION}

In order to establish value-for-money when implementing a system/technology implementation project, the affordability, technological change or advancement, and relevance of the system to operations and targeted expectations or projections are of essence. A study by Fiedler (2014) found that hybrid systems are cost effective. A report by Promethium and the South African National Energy Development Institute (2017) states that hybridised systems in the energy sector are normally pursued to replace and/or augment or boost conventional technologies with improved technologies such as renewable based energy technologies. A study by Abd El-Aal (2005) found that hybridisation is the best possibility for efficient use of locally available renewable energy sources. Primo (2016) concurs and states that hybrid systems provide a high level of energy security through a mix of generation methods. Thus, the funding for the implementation of hybrid systems is outlined with the aim of assisting the uMhlathuze municipality in decision-making regarding the procurement and implementation of hybrid systems as a new technique of improving the reliability and sustainability of delivering services.

\section{BACKGROUND}

Timmons, Harris and Roach (2014) point out that the majority of the world's energy supply has been dominated by the low cost of fossil fuel based electricity generation, but the cost advantage that fossil fuels have over renewable 
energy sources has significantly decreased to the extent that renewable can now compete with fossil fuels solely on financial terms. Further, the authors indicate that the forecast based on the continuous improvement of renewable technology is that renewable energy costs will decrease further making electricity generated from the use of renewable and improved technology affordable. Donastorg, Renukappa and Suresh (2017) concur stating that the current and ongoing cost reductions in renewable power generation technologies aid developing countries in achieving national and international energy and $\mathrm{CO}_{2}$ emissions policy goals as well as reliable energy security, affordable energy targets and promotion of access to electricity for all at a lower cost than traditional sources. Maheshwari and Jain (2017) echo the above views and state that the key to satisfying expected and projected targets on $\mathrm{CO}_{2}$ emissions and production of affordable and reliable electricity generation is the use of efficient renewable energy technology which includes photovoltaic such as in the PV-MFC hybrid system(s) to realise the shift towards de-carbonized electricity generation.

Donastorg et al. (2017) state that although the renewable energy industry faces an exponential increase in opportunity and challenge to grow the renewable energy business and financial strategies that effectively exploit renewable sources, government institutions such as municipalities must decide and commit on implementing financial strategies related to energy sector infrastructure renewable energy project. In 2009, the United Nations Environmental Program (2009) estimated that the renewable energy market is a 19-26 trillion-dollar investment opportunity. Taylor, Daniel, Ilas and Young (2014) estimate that living standards and energy demand is set to increase by $21 \%$ by 2030 making the renewable energy market a 23 trillion-dollar to 31.5 trillion-dollar investment opportunity by the year 2030 . According to Donastorg et al. (2017), the above relates to how energy sector growth impacts local economies and how the energy sector directly connects to the sustainability and vibrancy of the global economy.

Considering that energy is one of the main sectors that drives economic activity, any major decision made in the energy sector has significant ripple effects throughout a country's economy, especially for developing countries. Therefore, Donastorg et al. (2017) state that governments must have a high level of understanding regarding renewable energy investments because this requires intense and detailed feasibility studies of the type of renewable energy business being considered, proper financial analysis, and funding agreements to be put in place for the entire designed duration of the project. However, because of limited public funding, Donastorg et al (2017) suggests that donor funding must be pursued with the international community and/or partnership agreements with the private sector.

A study by Griffith-Jones, Ocampo and Spratt (2012) found that in most cases social costs are neglected in financial planning regarding energy infrastructure, yet they have great significance in terms of the overall social and environmental impact. The authors are of the view that the economics of renewable energy require incentives to gain investment in renewable. One way of doing this is to not only enumerate direct and immediate costs but also enumerate any contingent liabilities in the future, also known as negative externalities.

A negative externality is, for instance, the environmental damage caused by a conventional energy generating power station but which is not factored into the price, that is, costs associated with social impact such as environmental pollution. If these costs are factored in, then the generation costs are actually higher than the actual investment and operations costs. These are the private costs of conventional power plants and are generally borne by external third parties. Griffith-Jones et al. (2012) proposes that Pigouvian taxes (named after Pigou, 1932) which align private and social costs should be introduced. In this way, the price will reflect the true costs of conventional generation. Based on the views by Petrakis et al. (1997), Griffith-Jones et al. (2012) describes three forms of Pigouvian taxes: first, second or third best. With 
Pigouvian taxes in place, a shift from fossil fuel based generation to renewable energy based generation is inevitable (Griffith-Jones et al., 2012). Further, Griffith-Jones et al. (2012) state that since renewable based energy generation has extremely low social costs compared to fossil-fuel based costs, a well-calibrated Pigouvian tax on $\mathrm{CO}_{2}$ emissions (second best) or on fossil fuels (third best) would be sufficient for government to capture the true reflection of the costs associated with fossil-fuel based generation which will increase the electricity price and stimulate and encourage investment in renewable technology based generation. Thus, when planning finance for a renewable investment, Griffith-Jones et al. (2012) suggest that subsidies must be factored in or accounted for in a "blended finance" model through private public partnership (PPP) agreements to reflect both direct and indirect costs.

A study by Zvimba and Musvoto (2020) found that 55\% of the total energy used in South Africa is accounted for by municipal wastewater treatment processes (there are 824 municipal wastewater treatment plants). However, government institutions such as municipalities are wary of pursuing large-scale renewable energy projects because of the high initial investment costs. Costs associated with renewable technology in the preliminary stages are: feasibility costs that include establishing all the costs of procuring the technology required, costs of undertaking assessments and mitigating outcomes from risk and environmental impact assessments, legal and compliance costs, land costs, and all financing costs taking into account the viability of financing renewable energy technology and maintaining the finance agreement.

According to (CERC, 2013, as cited in Maheshwari and Jain, 2017), the initial costs associated with renewable technology such PV-MFC technology mainly comprise land costs, acquisition costs of procuring the technology, PV module and MFC plant costs, civil and general works costs, power conditioning unit costs, evacuation costs, and etcetera. The advantage that municipalities such as uMhlathuze municipality have is that the majority of the land in the area is municipality (government) owned and no evacuation is required, thus reducing initial costs by approximately $20 \%$. Maheshwari and Jain (2017) state that the actual amount depends on both internal and external factors including whether the technology is locally produced or not. Internationally produced renewable technology have associated costs that are influenced by the country's financial status and rating, and socio-economic and political factors such as import costs, transportation costs, customs (tax) costs, etcetera. In the context of this paper, initial means budgeted and allocated. Budgeted funds are funds that have been earmarked for allocation but have not yet been committed. Allocated funds are finances that have been identified and committed for undertaking the project concerned.

The study by the South African National Energy Development Institute (2017) reflects that employing a PVbioenergy hybrid system can have a payback period of between 4 to 6 years depending on the applicable grid-electricity fee structure and the demand profile. Although, the initial capital investment or outlay of PV-MFC hybrid-based technologies presents a barrier for the implementation of large projects, the benefits of having long-lasting, reliable and sustainable energy supply with very low or no carbon emissions and cheap electricity generation costs, according to South African National Energy Development Institute (2017), outweighs cost implications. Aznar, Logan, Gagne and Chen (2019) concur and state that some projects when evaluated might seem to be non-viable in terms of profits and/or energy saving, but non-energy benefits can qualify a project for implementation.

From a technical point of view, South African National Energy Development Institute (2017) indicates that bioenergy generation using a PV-MFC hybrid system is site specific and its feasibility and appropriateness is dependent on the availability and sustainability of renewable sources and the low cost of generating energy. According to Aznar et al. 
(2019), the following points need to be fully understood and addressed when designing and implementing a hybrid system that is intended to address energy shortages and exponentially growing energy demands:

- Define the target application because inadequate targeting may lead to misdirected energy subsidies.

- Decide on the most energy-efficiency investments that reduce long-term energy burden, yet maintain adequate supply that meets the demand and phase out conventional energy generation and bill assistance related subsidies in the long term.

- Attain adequate access, engagement and commitment of partners that support initiative(s) at all stages so that risk is shared and capital investment opportunities are heightened. That is, financial institutions and utilities must have full participation in the financing and delivering of identified feasible energy-efficiency initiatives.

- Ensure that a sustainable funding source and program are in place and well understood so as to meet as little resistance as possible.

- Ensure that the system is simple and can be easily integrated in phases by means of decentralisation.

- Ensure that the initiative (system or project) satisfies a tailor-made, flexible, multidimensional strategy that accounts for diverse participation with no or minimum resistance.

- Review the implementation strategy and application of the designed system with regards to relevancy, adaptability and productivity (Aznar et al., (2019).

Sweeney describes energy demand as being derived from preferences for energy services that depend on the properties of conversion technologies and costs. Energy economics involves looking at the forces influencing the use of energy resources, supply, demand, efficient use, and the economic distributional and environmental consequences. Energy is in economic terms referred to as an essential good that is always needed to sustain life and has a positive demand irrespective of how high its price becomes.

Project financing involves modelling and projecting anticipated income, and computing the internal rate of return of the project. Groobey, Faber and Klaus (2012) define project finance as the process whereby lenders loan money for the development of a project based on identified risks and future benefits such as cash flow and non-monetary benefits of implementing the renewable energy project. Capital project finance is a method that is described by Groobey et al. (2012) as involving the financing of a project in which the lender (in this case, the municipality) has either no recourse or limited recourse to the project funder that the lender is in agreement with.

\section{FUNDING FOR HYBRID SYSTEM}

Cost management according to Ramabodu (2014) involves:

- Cost design is the process whereby a renewable energy project is designed in such a manner that it satisfies all the outlined key parameters in the design, implementation and operation of the project based on the needs cost, opportunity cost and cost of acquisition of the renewable energy technology.

- Cost planning is the process used to ensure that all the anticipated final costs related to the completion and operation of the renewable energy project for the stipulated payback duration are completely covered in the 
feasibility study including cost of proposed land, legal compliance costs such as costs of conducting EIAs, site preparation costs, construction costs, tax costs (and for imported technology, all custom tax related costs including costs of checking technology against South African National Standards (SANS), and financing and management costs. This process aids budgeting by clearly setting out cost and budget targets.

- Cost control and cost checking process which is an audit exercise undertaken to correlate cost accountability to decision-making and vision (expectations) by both the municipality and other stakeholders such as the private entity and the community. This process ensures that all stakeholders (including the funder) are kept informed and that methods are regularly reviewed depending on the criticality to achieve best (desired) outcomes.

- Cost analysis involves analysis of items to provide useful cost information and data so as to identify major cost items, analyse annual user cost of ownership and shared resources and risks, funding type agreement costs and identify the groups of items of cost importance. This process examines and suggests the most cost-effective option that will enable successful achievement of targeted goals regarding completion and operation of the renewable energy technology project.

- Cost-benefit analysis, a complex process (based on views by Ashworth, 1994) that evaluates the economics of costs incurred in relation to the targeted benefits. This process (based on views by Ferry and Brandon, 1991) evaluates the monetary value of intangible aspects such as opportunity costs, social benefits, environmental impact costs, etcetera.

- Life-cycle appraisal and cost reporting, a process known as "cost-in-use", designed to model and evaluate the mixture of capital costs, running costs and cost of ownership of the renewable energy technology throughout its lifespan. This process uses forecasting of future value that reflects value for money giving full consideration to maintenance aspects and future costs. Based on the on-going costs relating to the renewable energy investment, accurate cost information and cost reporting are undertaken to all stakeholders for continuous proactive actions and reviews and the effective management of stakeholder expectations with regards to the effectiveness and efficiency of the renewable energy technology project (Ramabodu, 2014).

In light of the above views by Ramabodu (2014), the objective of this paper is to evaluate the financial viability of implementing a PV-MFC hybrid system to supplement electricity shortages, the financing models for renewable energy projects together with possible repayment or payback methods using net present value (NPV), return on investment (ROI) and payback period must be rigorously undertaken. Aznar et al. (2019) states that three main funding streams may be considered: government-directed taxpayer funding, state and utility directed funding by means of a surcharge, and leveraging private sector investment. Aznar et al. (2019) further state that conducting evaluations based on financing models provide an understanding of the project roll-out, integration and impact of the system on conventional generation, and the effectiveness of the revenue collecting method directed towards repayment against planned (expected) repayment goals.

Aznar et al (2019) states that the key yardstick for government in determining and prioritising the design and implementation of renewable PV-MFC projects that take into account energy efficiency is the use of cost-benefit analysis. Raissicharmakani (2018) points out that project viability may be compromised if the infrastructure condition subsequently requires improvement as embarking on such improvement can be costly and results in the project not passing the cost- 
benefit test. Government mandates utilities with a framework of how to generate revenue by means of billing, even though there may be other streams of income in place such as donor funding and/or government bailouts. In the context of this paper, the same principle can be applied to municipalities if they are given autonomy to generate their own energy for the purpose of providing services to the community and generating an income.

According to Shively (2012), benefit-cost analysis (BCA) is a technique commonly used to evaluate the economic merit of a project or an investment by comparing the economic benefits of undertaking an activity with the economic costs of the same. Although, the BCA can be used to compare competing projects, the principles of BCA in the context of this paper is to indicate how the benefits of implementing aPV-MFC hybrid system can be economically viable so that the uMhlathuze municipality can make an informed decision on behalf of the public they are serving regarding reliable and sustainable energy generation and supply, affordable energy access, conservation of natural resources by utilising resources that naturally replenish, climate management and reduction of $\mathrm{CO}_{2}$ emissions, legal compliance, and improved quality of life.

Shively (2012) states that it is important to know when benefits are realised and when costs are incurred. Shively (2012) introduces the concept of discounting, which is a technique of converting all benefits and costs into their value in the present time. This concept basically indicates that the future value of a benefit is discounted, thus the benefit received in the future is not of the same worth as the benefit received in the present. Although, discounting is the opposite of compounding present value of a benefit (amount) using an interest rate, the present value (PrV) of a benefit or an amount $\left(\mathrm{P}_{\mathrm{t}}\right)$ at some time in future is expressed by Shively (2012) as:

$$
\operatorname{Pr} V=\frac{P_{t}}{(1+r)^{t}}
$$

Where $\operatorname{PrV}$ is the present value of the investment amount, $P_{t}$ is the value of the future amount in time or period $t, r$ is the pre-determined discounted future rate, and $t$ is the year in which $P_{t}$ is realised.

Although $\operatorname{PrV}$ is also used to evaluate between two investments in preparation for the best-suited investment, for this paper, the focus is establishing if the future value of the benefits of implementing a hybrid system exceeds the initial investment cost. The other aspect of $\operatorname{PrV}$ relevant to this paper is establishing the opportunity cost of capital investment at the discounted rate determined by the type of agreement entered to. Shively (2012) describes opportunity cost of capital investment as the returns (amount of benefits) that would be received if the funds were directed or invested elsewhere, say in another project. With the latter view, often the discounted rate is set equal to the interest rate. The discounted rate, according to Shively (2012) when looking at the opportunity cost, is called the social rate of time preference (SRTP), which indicates how society at large ought to value the future. Shively (2012) states that the SRTP is normally lower than the discount rate because in general society prefers to consume the project related benefits sooner rather than later. Thus, communities are biased or inclined towards projects that exhibit benefits now (at the present moment). Due to this fact, municipalities tend to choose projects that will bring the community immediate benefits such as increasing the house connections for community members to have access to water rather than building a reservoir.

Amongst other tools that can be used to aid investment decisions or project implementation when using BCA are:

- The net present value (NPV) computes the current value of a project's net benefits in any period of time by using the expression: 


$$
N P V=\sum_{t=0}^{T} \frac{\left(B_{t}-C_{t}\right)}{(1+r)^{t}}
$$

Where $B$ is the benefit and $C$ is the cost. The NPV tool determines if a project can be implemented. Thus, Shively (2012) states that when NPV is greater than zero then the project can be undertaken.

- The benefit-cost ratio (BCR) determines if the benefits outweighing the costs can be calculated by using the expression that indicates the ratio of the PrV benefits divided by the PrV of costs. The expression is:

$$
B C R=\frac{\sum_{t=0}^{T} \frac{B_{t}}{(1+r)^{t}}}{\sum_{t=0}^{T} \frac{C_{t}}{(1+r)^{t}}} .
$$

When $B C R$ is greater than one, the project can be accepted for implementation.

- The internal rate of return (IRR) reflects the maximum interest that can be paid for the project resources and pay for the investment and operating costs but still allow for the municipality to break even. Shively (2012) describes IRR as the discount rate for which the present value of total benefits equals the present value of the total costs. The IRR is computed using the expression:

$$
\operatorname{PrV}(\text { benefits })-\operatorname{PrV}(\text { costs })=0 \text {. }
$$

When the IRR is greater than the discounted rate, the project can be approved similarly to when calculating BCR.

Aznaret al (2019) provides an additional analysis or test that can be employed by any country or government attempting to increase its energy security and sustenance and improved energy efficiencies, the savings-to-investment ratio (SIR). When the savings-to-investment ratio is 1 or greater, the present value of the system and energy efficiency measure during its lifetime is greater than the costs, so the investment can be undertaken as this means that the energy that the system generates together with associated energy efficiencies is fully recoverable in terms of energy savings. Further, based on the views of Lazar and Colbrun (2013), Aznaret al (2019) indicate that some systems or projects might not exceed the benefit-cost ratio of 1 when accounting solely for the energy benefits, but when non-energy benefits (which are complex to quantify) are considered, the system or project becomes viable for implementation. Aznaret al (2019) suggests that survey and site evaluation methods must be used to estimate the value of non-energy benefits.

Although utilities in most cases design and source their own funding mechanisms, government still play a vital role by acting as surety to financial institutions such as the World Bank and IMF when loan arrangements are pursued, regulating charges levied to consumers and promoting and protecting local generation from competition from multinational companies that seek to take revenue and profits generated elsewhere. Karekezi, Lata and Coelho (2004) (2004) (citing Zhou, 2003) state that the problem faced by Africa is not the increase in energy consumption per se, but the lack of attention that renewable energy based projects receive from the various government structures in the African continent in terms of funds and research that has resulted in energy supply paradigms being unaffordable. In support of the above views, Onyekwelu and Akindeke (2006) state that the economies of various African countries together with their governments are dominated by a few profit-driven multinational corporations that African governments tend to pay allegiance to, to the detriment of their citizens. 
While the investment modes and tools reflected above assist in decision-making towards the implementation of a hybrid system, the payback period must be indicated as no project can be undertaken to have indefinite payback period, thus the payback aspect of financing renewable energy projects must be critically evaluated as an important component. Zamfir, Manea and Ionescu (2016) state that return on investment (ROI) is an important tool or technique that investors can use to assess the extent to which an investment will produce gain from the use of capital. Thus, ROI is used in performance analysis and decision-making to aid in determining the efficiency of the capital amount invested. Zamfiret al (2016) indicates that the ROI can be computed using the expression:

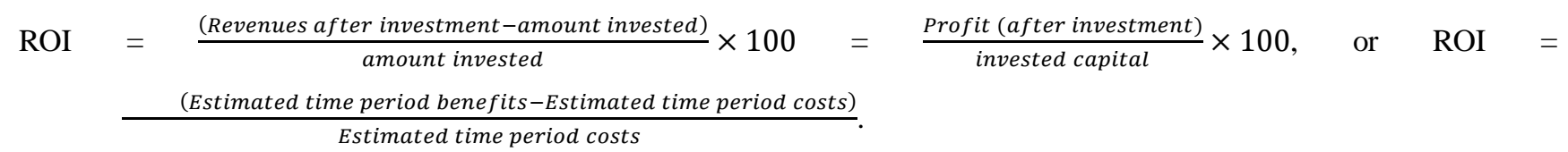

The operating cycle of an initial capital investment requires short-term funding called working capital (WC).WC is the difference between initial invested capital (IC) and fixed assets (FA) and is expressed as WC=IC-FA. Computation of WC creates a holistic investment outlay for the renewable energy project because the balance of the invested capital available after financing fixed assets is then a funding resource that covers the capital needs generated by the operating cycle.

Rashford, Macsalka and Gieger (2013) state that the general norm when procuring renewable energy technologies is that the decision to purchase is rarely based on costs alone, but other factors such as social and environmental aspects. Furthermore, the authors state that one of the most requested measures of capital budgeting for a renewable energy system's economic feasibility is payback. Payback is the point in time at which initial investment is paid off, so calculating the payback determines the number of years for the energy savings from the renewable energy system to completely off set the initial investment cost. Payback can be computed using the expression:

$$
\text { Payback }(\text { years })=\frac{\text { Initial investment cost }(\text { in Rands })}{\left[\begin{array}{c}
\left.\left[\left(\text { annual energy production in } \frac{\mathrm{kWh}}{\text { year }}\right) \times \text { market price paid for energy }\right]\right] \\
-(\text { Operations and maintenace costs } \text { in rands } / \text { year })
\end{array}\right]}
$$

In agreement with the view by Rashford et al (2013), Kessler (2017) states that although the term 'payback' is loosely used, the technical and financial aspects of a project must be addressed and the simple payback period (SPB) provides an estimate of expenses and returns, and energy payback (EPB) must be considered for renewable energy projects. Based on views by Suri, Huld, Dunlop and Ossenbrink (2007), Kessler (2017) states that the SPB may be computed using the expression:

$$
\mathrm{SPB}=\left(\mathrm{C}_{\text {system }}\right)\left(\mathrm{Q}_{\text {year }}{ }^{-1}\right)\left(\mathrm{PR}^{-1}\right)\left(\mathrm{P}^{-1}\right)\left(\mathrm{C}_{\text {elec }^{-1}}\right) \text {. }
$$

Where $\mathrm{C}_{\text {system }}$ is the un-subsidized installed system cost, $\mathrm{Q}_{\text {year }}$ is the total annual renewable resource collected annually using optimal harnessing of renewable energy such as maximum irradiation collected at optimally inclined array of modules at a specific location, PR is the system's annual DC to AC performance ratio (Marlon et al., 2005 as cited by Kessler (2017)), $\mathrm{P}$ is the system DC capacity in Watts, and $\mathrm{C}_{\text {elec }}$ is the cost of electricity at the market electricity rate.

When examining the viability of energy investment, the EPB is expressed as:

$$
\mathrm{EPB}=\left(\mathrm{E}_{\mathrm{M}}+\mathrm{E}_{\mathrm{INV}}+\mathrm{E}_{\mathrm{BOS}}\right)\left(\mathrm{Q}_{\text {year }}^{-1}\right)\left(\mathrm{PR}^{-1}\right)\left(\mathrm{P}^{-1}\right) .
$$


Where according to Peng, Lu and Yang (2013), $\mathrm{E}_{\mathrm{M}}, \mathrm{E}_{\mathrm{INV}}$, and $\mathrm{E}_{\mathrm{BO}}$ represent the embodied energy of the renewable technology such as that of the solar modules of the PV-MFC hybrid system, the DC-to-AC inverters, and the balance of system (BOS), respectively. Kessler (2017) indicates that SPB is a tool that estimates the period of time required to recoup the initial capital outlay, whereas EPB computes the time required for the hybrid system to generate an amount of energy that is equivalent to the initial energy inputs and start net energy production.

Payback calculations have limitations in not being able to factor in some critical investment characteristics such as time value of money (which includes inflation), associated investment risk and the opportunity cost of investment; escalations in energy prices. Nevertheless, the payback technique gives a quick evaluation of project(s) feasibility in terms of recovering initial investment made. However, an additional measure is required to provide a detailed assessment of the project feasibility. Since the initial investment involves capital budgeting (a process that Rashford et al. (2013) describe as being used to evaluate specific investment decisions), detailed investment characteristics must be accounted for, using NPV. NPV computes the difference between the present value of the future net cash flow of an investment made on a project and the net initial cash outflow using the discount rate. For a significant investment such as that of implementing a scaled-up renewable PV-MFC hybrid system, the profitability index of the project must be established. The project profitability index is the ratio of NPV of the project's future cash flows to the initial investment required. Zamfiret al.

(2016) echo the above and states that NPV enables the analysis of investment for different dates and times of the renewable energy project by quantifying the flow that will achieve future anticipated value with current investment value. The updated expression that quantifies the influence of time on the efficiency investment is according to Zamfiret al. (2016):

$$
N P V_{t a}=I_{t}+\sum_{h=1}^{D} C F(1+i)^{-h} .
$$

Where $N P V_{t a}$ is the total net present value, $I_{t}$ is the total investment, $C F$ is the discounted net cash flow accumulated during the effective period of functioning of the investment objective, $D$ is the number of effective periods of functioning of the objective, $h$ is the period of investment, $i$ is the discount rate. Zamfiret al. (2016) states that for each investment period it is calculated, the discount coefficient is $\mathrm{c}=(1+0,1)^{-\mathrm{h}}$.

McGee (2014) indicates that when undertaking due-diligence on project feasibility, multiple tools must be employed to ensure that the project pursued satisfies all expectations, including break-even analysis. Break-even analysis is described by McGee (2014) as an attempt to estimate the point at which the benefits equal the costs of undertaking the project. This is very complex when factoring in non-monetary value (non-energy profit) and auxiliary benefits such as community and industrial relief and confidence in a new energy supply endeavour, the long-run (accumulated) environmental impact of apparently insignificant (often treated as neglected) discharges to the environment, the increased population attraction due to increased security of supply, etcetera. The break-even method assists in evaluating the required volumes of generated and supplied energy at particular discounted rates (rates normally used by utilities, in this case ESKOM) to break even in relation to the opportunity cost of expanding the national grid that generates energy conventionally (using coal) by the same capacity. Although some aspects might be complex to quantify, McGee (2014) states that when using the cost structure in undertaking the break-even analysis, the cost items that make up most of the total expenditure are easily identified, ways of by how much (and how) the costs can be reduced become evident, and the costs that are controllable (and which are not) can be identified for overall decision-making. 
In support of using break-even analysis, McGee (2014) suggests that demand tests and sensitivity tests must be conducted. The demand test, according to McGee (2014), can be conducted to establish the break-even point, both theoretically and practically, and the discounted price value must be used to accommodate potential risks and targeted profits when financing the project. Further to the demand test, McGee (2014) states that a sensitivity test must be undertaken on price to assess the impact on contribution margins and the consequent effect required to reach the breakeven point and the corresponding market performances.

Saywell, Culler and Woods (1995) state that when conducting a break-even analysis using the cost structure, the associated costs of implementing and operating a project must be based on two cost categories, namely, variable costs that are highly dependent and influenced by the energy generation yield and fixed costs that can either be direct or indirect but do not vary with energy produced. The authors identify direct fixed costs as being wages of personnel that are responsible for the production of energy from the use of the hybrid system and indirect fixed costs as infrastructure costs such as equipment depreciation. Classifying costs as above and accounting for each respective cost item together with conducting the demand and sensitivity tests enables the effective management of fiscal viability and reduction of identified cost drivers

Tongsopit, Mounghareon, Aksornkij and Potisat (2015) state that business models and financing options play a significant role in driving the implementation of a scaled-up renewable energy power generating hybrid system. The authors list appropriate business models as:(1) entering either into a lease agreement, or rental arrangement, or purchase agreement whereby the system is procured for implementation and operation purposes under the total ownership of the municipality or (2) a stakeholder (community and/or industry) initiative partnership whereby industry and the community commit funds and the municipality commits land and/or funds towards purchasing and co-owning the system that the municipality operates on behalf of all shareholders. Normally, government institutions such as municipalities do not lease or rent capital infrastructure projects in the energy generation and supply sector. Thus, the financing options of either using a financial institution to loan or donor funding or public-private partnership (PPP) to get funds for the renewable energy power project must be matched with the selected business model to satisfy expectations.

The three pillars that fully and effectively address expectations related to implementing a renewable energy power plant are: (1) targeted output of the product and end-user needs and demands; (2) the business model which directly influences the financing option, profits, and payback period of the project; and (3) the financing option which influences the feasibility of the project in terms of repayment agreements (amounts and conditions of repayment). Fundamental components of this approach are the use of payback and NPV to stimulate management decision making towards implementing the project and the use of cost-benefit analysis to effectively conduct the break-even analysis with all factors considered (including risk profile and demand and sensitivity tests) so that stakeholders can know, by when the benefits at discounted future rates are likely to break-even with the initial investment costs. Upon establishing the above, Tongsopit and Greacen (2013) support the 'adder scheme' that gives power producers that sell electricity produced by renewable energy means certain tariffs for a specified period of time allowing power producers to incorporate an adder rate for every kilowatt hour (kWh) produced on top of the utility electricity price. Cory, Couture and Kreycik (2009) termed the incorporation of the adder rate the premium-price feed-in tariff.

Although self-financing is commonly used world-wide as a conventional way of financing, due to the heavy burden posed by the associated risks of self-financing, the 2019 National Business Initiative Report (2019) states that in 
1999 the South African government through the National Treasury introduced the PPP concept for procurement purposes. APPP is aimed at leveraging private party capital to fund infrastructure and private sector skills to supplement government institutions to reduce concentrated financial risk to government and spread the financial risk over the lifecycle of the project, and create budgetary certainty. Since conducting a feasibility study and implementing a renewable energy power generating project at up-scaled magnitudes is extremely costly and sensitive to government and community interest, PPP agreements are becoming more common in addressing financing of local government (municipality) initiatives. PPPs have played a key role in accelerating the adoption (decision-making and approval) of energy efficiency, water conservation, and energy generation projects. The RES4MED \& Africa (2018) report concurs with the above and states that PPP agreements are preferred by most government institutions or agents because they carry build-own-operate (BOO) contracts that ensures shared liability initially as the asset only changes to the asset register of the municipality when the payback is completed. The study by (2012) reflects that there is a growing trend of PPP agreements in developing countries in financing renewable energy projects and technologies. However, third-party financing that involves government in South Africa has caused a lot of controversies and scepticism when it comes to the procurement of renewable energy technology such as PV-MFC hybrid systems, thus there is resistance towards this mode of financing.

According to Timmons, Harris and Roach (2014), the levelized cost of energy (LCOE) is the cost (at present value) of building and operating a renewable power plant over an assumed lifetime. Timmons et al (2014) states that the purpose of LCOE at present value is to mitigate the effects of inflation. The levelized cost (LC) of implementing and operating the power plant, according to Timmons et al. (2014), is divided by the total energy obtained so that direct comparisons across the different energy sources can be made. The LCOE provides an indication of the wholesale electricity price (Timmons et al., 2014). South African National Energy Development Institute (2017) suggests that hybrid systems are becoming more cost effective and efficient in generating electricity, more so than fossil fuel based electricity. The current challenges of renewable energy based generation are high initial investment costs, the energy costs of meeting current energy demands from communities and various other users, the opportunity costs associated with reluctance of government buy-in on renewable energy generation, and the opportunity cost of undertaking capital refurbishment or rehabilitation on 'live' conventional (fossil-fuel based) power generating plants.

It takes energy to produce energy; net energy ratio (NER) is the energy available for final consumption divided by the energy required to produce it (Timmons et al., 2014). The NER indicates the margins of energy from an investment: when the NER is a large value this means that there is a significant amount of energy produced from a small energy investment. Timmons et al. (2014) further states that net energy is a physical attribute of an energy source, a component of energy cost that relies on the efficiency of the technology used to reduce energy required because efficiency results in the fall in $\operatorname{cost}(\mathrm{s})$ of generating electricity.

Zamfir et al. (2016) state that the limitations of capital financing tools such as ROI and other financing options is that the focus is on the financial side of investment(s) which ignores other project related benefits such as improved quality of life and satisfaction of the community, positive project impact on the environment, positive image or credibility of the municipality regarding effective and efficient delivery of energy and technical services to the community, energy and resource conservation through improved efficiency savings, etcetera. 


\section{RECOMMENDATIONS}

Renewable energy projects are critical to the reliable development and socio-economic welfare of the residents and industries served by local government institutions such as uMhlathuze municipality. Renewable energy projects are multidisciplinary in nature and require the appointment of municipal specialists that will deal with forecasting the energy and other technical needs by the municipality in providing effective services. Although the municipality has planning divisions in the water and sanitation section and the electricity section, the municipality needs to establish a research and development (R\&D) division that will look at how municipal services can be improved using innovative means such as procuring PV-MFC hybrid technology for the municipality to be efficient in serving the community. Thus, the municipality should hire competent specialists and advisors such as industrial engineers (who are generally not hired in the municipal environment) and other specialists to provide the municipality with a map or guide on how to serve future demands in the energy and water sectors.

The personnel involved in large capital investments must be kept separate from operational matters so that such personnel can focus on effective innovations that are communicated regularly to the Council based on developing or new demand, changes in socio-economic activity, and alignment with legislative prescripts. The R\&D team should comprise project managers, technical financial officers that deal with technical procurement and large projects, industrial engineers and economists that focus on forecasting on all essential services and seek for financial aid on capital projects, legal personnel that focus on government initiatives such as the PPP agreements and large scale contracts, and environmental specialists that deal with the impact of large-scale projects on the environment. The hiring of the above-listed personnel inhouse reduces the risks and liabilities that the municipality currently encounters with agreements such as PPP agreements, and the costs of hiring professional service providers (consultants) to conduct feasibility studies and finance agreements that advantage the same service providers and prejudice the municipality in one way or the other as different financial institutions have different requirements. The scope of the R\&D team would be to conduct due diligence on capital project matters using, among others, the tools discussed in this paper to evaluate the feasibility, profitability and cost-effectiveness of the intended capital investment and disclosing the associated benefits of embarking on the such an investment.

\section{CONCLUSIONS}

Promethium Carbon and South African National Energy Development Institute (2017) states that in order to access clean and stable energy and meet sustainable development goals in the energy sector requires migration by developing countries from fossil fuel dependency to renewable energy source(s) engagement. Access to and financing of renewable energy projects are major challenges for many developing countries such as South Africa, but PPP agreements using wellstructured financing models that account for discounted future value of renewable energy projects in terms of money and socio-economic impact is a step in the right direction.

\section{REFERENCES}

1. Abd El-Aal, A.M. (2005). Modelling and simulation of a photovoltaic fuel cell hybrid system. Doctoral thesis. University of Kassel, Kassel, Germany.

2. Aznar, A., Logan, J., Gagne, D and Chen, E. (2019). Advancing energy efficiency in developing countries: Lessons learned from low-income residential experiences in industialized countries. National Renewable Energy Laboratory. USAID-NREL partnership. USA 
3. Fiedler, F. (2014). PV hybrid systems. Solar Energy Research Center: Lecture Notes. Hogskolan Dalarna.

4. Promethium Carbon and South African National Energy Development Institute. (2017). Technical Report: Appraisal of implementation of fossil fuel and renewable energy hybrid technologies in South Africa. Retrieved from https://www.sanedi.org.za/img/wp-content/uploads/2018-01-

15\%20Hybrid\%20Technologies\%20in\%20South\%20Africa\%20full\%20report.pdf.

5. Rahimnejad, M., Adhami, A., Darvari, S., Zarepour, A., and Oh, S.E. (2015). Microbial fuel cell as new technology for bioelectricity generation: A review. Alexandria Engineering Journal, 54, 745-756.

6. Raissicharmakani, S. (2018). A programmatic assessment of the U.S. Department of Energy Low-income Weatherization Assistance Program. Master's thesis, University of Michigan. https://deepblue.lib.umich.edu/bitstream/handle/2027.42/143155/RaissiCharmakani_Shiva_Thesi s.pdf? sequence $=1$ \&isAllowed $=y$.

7. Shively, G. (2012). An overview of benefit-cost analysis. Purdue University. Available http://www2.econ.iastate.edu/classes/crp274/swenson/URP290/Readings/Purdue_An\%20Overview\%20of\%20Benefit.pdf.

8. Rashford, B.S., Macsalka, N. and Gieger, M. (2013). Renewable energy investment analysis: What's the payback? United States of America. University of Wyoming: Extension. Available http://wyomingextension.org/agpubs/pubs/B1235.pdf

9. Ardalan, K. (2012). Payback period and NPV: Their different cash flows. Journal of Economics and Finance Education, 11(2), 10-16.

10. McGee, J. (2014). Break-even analysis. In Wiley Encyclopaedia of Management. John Wiley and Sons. https://doi.org/10.1002/9781118785317.weom120065

11. Rai, Rachana, and Neeta D. Sharma. "Renewable energy in Sikkim." (2014).

12. Saywell, R.M., Cordell, W.H., Nyhuis, A.W., Giles. B.K., Culler, S.D. and Woods, J.R. (1995). The use of a break-even analysis: Financial analysis of a fast-track program. Academic Emergency Medicine, 2(8), 739-745.DOI: 10.1111/j.15532712.1995.tb03628.x

13. Tongsopit, S., Mounghareon, S., Aksornkij, A. and Potisat, T. (2015). Business models and financing options for a rapid scaleup of rooftop solar power systems in Thailand. InS. Kimura, Y. Chang and Y. Li (eds.).Financing renewable energy development in East Asia Summit Countries (pp. 79-136). ERIA Research Project Report 2014-27, Jakarta.

14. Upadhyay, A. S. H. O. K. "Review of Regulatory Promotional Initiatives for Development of Renewable Energy Projects in India." Int. J. Elec. Electron. Eng. Res.(IJEEER) 4 (2014): 9-24.

15. Cory, K., Couture, T. and Kreycik, C. (2009), Feed-in tariff policy: Design, implementation, and RPS policy interactions. Available: http://www.nrel.gov/docs/fy09osti/45549.pdf.

16. Tongsopit, S. and Greacen, C. (2013). An assessment of Thailand's feed-in tariff program. Renewable Energy, 60, 439-445.

17. Thakur, Robin, et al. "A review of integrated renewable energy system in power generation." Int J Mech Prod Eng Res Technol, 3, 7988 (2013).

18. National Business Initiative Report. (2019). An introduction to PPPs in South Africa. KopanoyaMetsi.

19. Timmons, D., Harris, J.M. and Roach, B. (2014). The economics of renewable energy. Global Development and Environment Institute, Tufts University, Medford MA, USA. Available: https://www.bu.edu/eci/files/2019/06/RenewableEnergyEcon.pdf 
20. Agrawal, Meena, et al. "Priority based strategic modes of operation and control for renewable energy sources microgrid." Materials Today: Proceedings (2020).

21. Donastorg, A., Renukappa, S. and Suresh, S. (2017). Financing renewable energy projects in developing countries: A critical review. IOP Conference Series: Earth and Environmental Science. 83.012012. doi :10.1088/1755-1315/83/1/012012.

22. United Nations Environmental Program. (2009). Private financing of renewable energy: A guide for policymakers. Available: https://www.chathamhouse.org/sites/default/files/public/Research/Energy,\%20Environment\%20and\%20Development/1209_fi nanceguide.pdf

23. Sari-Ali, I., B. Chikh-Bled, and B. Benyoucef. "Effect of shading on the performance on solar photovoltaic." Int J Appl Eng Res Dev (IJAERD) 4.2 (2014): 41-8p.

24. Taylor, M., Daniel, K., Ilas, A. and Young S. E. (2014). Renewable power generation costs in 2014. International Renewable Energy Agency, Bonn, Germany. Available: https://irena.org//media/Files/IRENA/Agency/Publication/2015/IRENA_RE_Power_Costs_2014_report.pdf

25. Griffith-Jones, S., Ocampo, J.A. and Spratt, S. (2012). Financing renewable energy in developing countries: Mechanisms and Responsibilities.

European

Commission.

http://www.stephanygj.net/papers/Financing_Renewable_Energy_in_Developing_Countries.pdf

26. Joshi, Krishna. "Application of Energy Concepts for Green Buildings." International Journal of Civil, Structural, Environmental and Infrastructure Engineering Research and Development (IJCSEIERD) ISSN (P) (2016): 2249-6866.

27. Sweeney, J.L. Economics of energy. Stanford University. Available: https://web.stanford.edu/ jsweeney/paper/Energy\%20Economics.PDF

28. Maheshwari, H. and Jain, K. (2017). Financial viability of solar photovoltaic system: A case study. International Journal of Civil Engineering and Technology, 8(11),180-190.

29. RES4MED \& Africa. (2018). Project finance for renewable energy systems: Egypt case study. Risk analysis and mitigation measures in the existing policy and regulatory framework. Available: https://www.res4med.org/wpcontent/uploads/2018/11/Project-Finance-Egypt_FINAL_WEB_VERSION-2.pdf

30. Ramabodu, M.S. (2014). Procurement guidelines for project success in cost planning of construction projects. Doctoral thesis. University of Free State, Bloemfontein, South Africa.

31. Groobey, C., Faber, M. and Klaus, M. (2012). Project finance for renewable energy and clean technology projects. Wilson Sonsini Goodrich \& Rosati. Available: https://www.wsgr.com/publications/PDFSearch/project-finance-renewable-energyprimer-0312.pdf

32. Kessler, W. (2017). Comparing energy payback and simple payback period for solar photovoltaic systems. E3S Web of Conferences. Vol. 22(00080). EDP Sciences. St, Portland. USA. DOI: 10.1051/e3sconf/20172200080

33. Peng, J., Lu, L., and Yang, H. (2013). Review on life cycle assessment of energy payback and greenhouse gas emission of solar photovoltaic systems. Renewable Sustainable Energy Reviews, 19, 255-274

34. Zamfir, M., Manea, M.D and Ionescu, L. (2016). Return on investment - indictor for measuring the profitability of invested capital. Valahian Journal of Economic Studies, 7(21), 79-86. DOI 10.1515/vjes-2016-0010.

35. Primo, J. (2016). Solar and Fuel Cells Technology Fundamentals \& Design. PDH Center. [Available online: www.PDHonline.org] 
36. Zvimba, J.N. and Musvoto, E.V. (2020). Modelling energy efficiency and generation potential in the South African wastewater service sector. Water Science \& Technology, 81(5), 876-890.

37. Karekezi, S., Lata, K. and Coelho, S.T. (2004). Traditional biomass energy: Improving its use and moving to modern energy use in renewable. 2004 International Conference for Renewable Energies.

38. Onyekwelu, J.C and Akindele, S.O. (2006). Biomass and bioenergy research in tropical Africa: State of the art challenges and future directions (pp. 1-34). In: D. M. Brenes (ed). Biomass and bioenergy: New research. Hauppauge, NY: Nova Science Publishers. 
